\author{
Zeynalov Zakir Gadzhi, \\ Ph.D., Associate Professor, Azerbaijan State University of Economics, Azerbaijan \\ (1) ORCID ID, 0000-0001-8110-3025 \\ email: zakir_zeynalov@unec.edu.az
}

\title{
INNOVATION IN LEASING AND LEASING OF INNOVATION: A META-ANALYSIS
}

Abstract. The paper deals with the analysis of the approaches in defining the main research directions in the field of leasing of innovations and innovations in leasing. Developing the Internet and expansion of mobile Internet, the advent of the Internet of Devices, Fintech, Insurtech and development of sharing economy provokes many debates about the future of innovation within the asset finance and innovation in the leasing of assets. This paper aimed to determine the scientific publication tendencies in the field investigating the issues on leasing of innovations and innovations in leasing to identifying prospective research areas. The methodological instruments of this paper are bibliographic tool VOSviewer, Scopus and Web of Science (WoS) databases. The study sample is 2513 scientific documents, published in the scientific journals indexed by Scopus (1915 documents) and WoS (598 documents) databases. The study has no limit time sample. The obtained results by Scopus and WoS tools showed the growing publication tendencies on the investigated issues. Besides, the number of papers in Scopus database had a growing tendency with a variable rate. There is a significant increase in the number of papers that occurred from 2000 to 2010. In turn, the number of paper in journals indexed by WoS had been regular rising during the analyzed period with a growth rate of $19,9 \%$. Thus, this database shows a considerable growth of publications from 2010 to 2019. In 2019 the number of articles in the field of leasing of innovations and innovations in leasing increased by $412 \%$ compared to 2010. Therefore, the investigated issues remain popular in investigations of the great string of the scientists. In the Scopus database, mostly the issues on leasing of innovations and innovations in leasing were investigated under the subject area as follows: Medicine, Engineering, Social Sciences, Environmental Science, Business, Management and Accounting, Computer Science. The author noted that the most significant part of the scientists which analyzed the leasing of the innovations and innovations in leasing was from the USA, China, United Kingdom and Germany. Herewith, in 2019, the number of papers devoted to investigated issues enhanced in scientific journals with high impact factors such as Land Use Policy, European Journal of Operational Research, Ecology and Society. Therefore, it indicates that investigated issues are actually in the trends of sharing economy. The obtained results by VOSviewer analysis allowed identifying six clusters of the scientific publications scrutinized the leasing of the innovations and innovations in leasing from different perspectives. It worth to mention that three out of six clusters have a close connection. The first biggest cluster links the keywords as follows: sustainable development, environmental impact, environmental protection, energy policy, land use, land management, fishery management, laws and legislation, risk assessment, etc. In turn, the second cluster indicated on the investigations in the sphere of information system and software in leasing. Three clusters (the third, fourth and fifth) are connected by the words «leasing - legal aspect health care/medical practice management - hospital equipment/hospital information system», etc. The keywords such as financial management, taxes, capital financing, leasing - property, capital expenditure, accounting, legal aspect, management and tax connected them with the sixth cluster.

Keywords: innovation, leasing, leasing management, innovation in leasing.

Introduction. The ongoing tendency on extending the use of big data by the Internet, expansion of mobile Internet, the advent of the Internet of Devices, Fintech, Insurtech etc. has made changes in connections of assets owners and people, who need these assets. That could also be referred to as the sharing economy (collaborative consumption, collaborative economy or peer economy). Besides, it includes a new level of business to business (B2B) interactions. According to data provided by the Brookings Institute (Governance Studies at Brookings, 2020) «...private vehicles go unused for 95 per cent of their lifetime. Together with the fact that there are fewer requirements to drive for Lyft, Ola and

Cite as: Zeynalov, Z. G. (2020). Innovation in Leasing and Leasing of Innovation: A Meta-Analysis. Marketing and Management of Innovations, 4, 202-218. http://doi.org/10.21272/mmi.2020.4-16 
Uber than for a taxi company mean a greater supply of rides. Prices of shared services are also falling, as indicated by Airbnb rates that are between 30 and 60 per cent cheaper than hotel rates around the world». This tendency provoked many debates about the future of innovation within the asset finance and innovation in the leasing of assets. The examples are the Leaseurope CEO Business council (Verdict Staff, 2013), where industry chiefs discussed ideas related to innovation and inviting gifted employee, or a platform Asset Finance International, where Andrew Denton, chief operating officer at CHP Consulting started the debate in this area. It stands to note that data from Google trends confirmed the mentioned above (Figure 1).

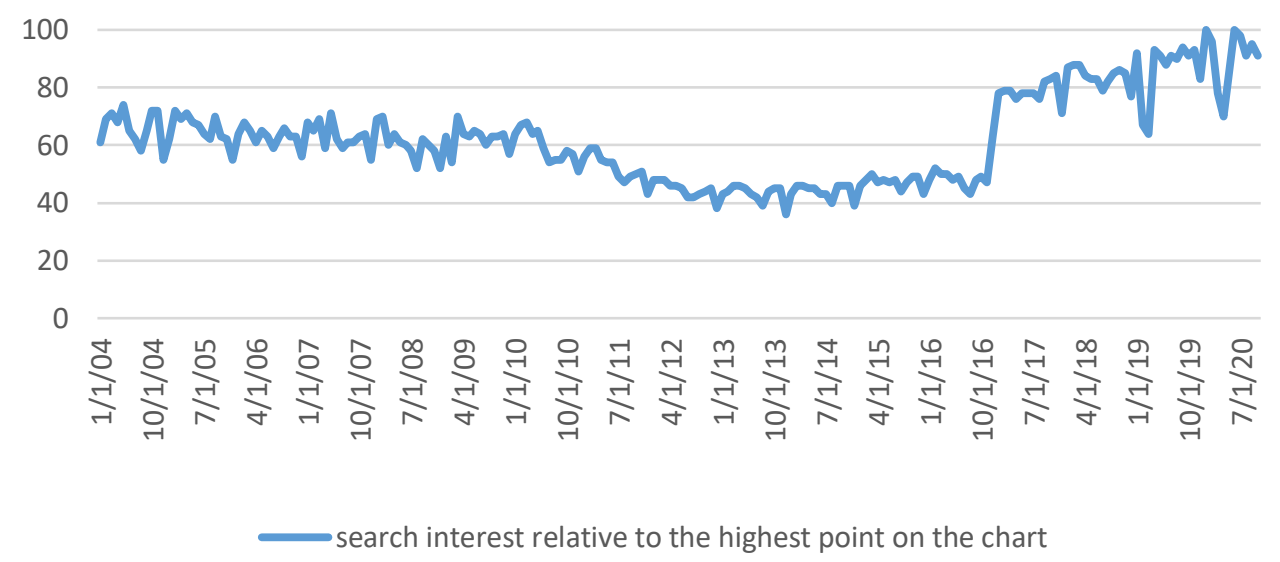

Figure 1. Search interest on the topic of "Leasing" from 2004 to 2020 (month changes)

Sources: developed by the author using data from Google Trends.

This research provides a literature survey on direct of the associations of keywords in areas of innovation and leasing. One of the main aims is to find a response to the question that keywords have strong relatedness with the leasing of the innovations and innovations in leasing. For gaining this goal, the scientific articles in the sphere of innovation and leasing were juxtaposed. Some historians and economists (CLEO, 2007) believe that the first mention of leasing transactions was on the clay tablets found in the Sumerian city of Ur. That contained information about the lease of agricultural implements, land, water sources, cattle and other animals in the Hammurabi Code. In turn, the great string of scientists published recently dedicated their papers to the leasing of the innovations and innovations in leasing. The scientists proceeded in the directions of financial and operation management, green leasing and development of supporting soft, etc. Note, that traditionally leasing analyzed with cost and financial management. The investigation based on the scientific articles published in the journals indexed by Scopus and/or Web of Sciences databases. This paper intentioned that as a perspective direction of research, it would be appropriate to analyze the connections between innovation in the leasing of the innovations and innovations in leasing and taxation.

Literature review. The common use of leasing terminology in scientific and academic writings is closely connected with the cost management, question «lease or buy» and choosing between loan and leasing. The oldest paper dedicated to leasing in the WoS database is the article (Grosset, 1970). Unfortunately, there is no possibility to find the full text or even abstract of this paper to understand its content. Besides, there is the same situation with the oldest paper connected with leasing in the Scopus database (Birtcher, 1959). But according to indexed keywords of this article, it covers the topic of hospital management. It could be assumed that it is dedicated to an innovative tool for obtaining medical 
equipment, without attracting significant initial investment. This paper stated a large amount of paper in sphere medical management. According to the WoS, the first paper in this area was published only in 2000 (Reiner et al., 2000). The authors of this paper aimed to evaluate the financing strategies for the acquisition of image archiving systems and communications in radiology, taking into account different sides of this choosing such as the technology obsolescence protection, financing of upgrades, purchaseend-of-term options, fair-market-value of the purchasing, guarantees etc. One of the recent papers dedicated to the leasing in health management and published in the journal indexed by Scopus is the article (Prideaux, et al., 2019). This paper aimed to analyze the rationale for curriculum leasing in Australian medical schools in earlier 2000. Herewith, the leasing enabled in short start up times to arrange inviting of required staff, get facilities and comply with accreditation requirements in time. Although, it increased the current expenses and determined the curriculum without possibility to change it. A separate direction of investigation is the place of leasing in management decision. The oldest article, according to Scopus database, was published in 1974 (Vigano, 1974). This parer considered the accounting aspects of leasing to develop and provide a general contribution to the theory of accountancy in Italy. The newest one is paper (Zhang et al., 2020) that compares the dynamic correlation and lead-lag relationship between the different financial approaches within the banking sector (traditional bank loans versus innovative financial leasing) and economic growth. According to WoS, the oldest article is paper (Baumel and Wallize, 1972) dedicated to the economic justification of choice between leasing and acquisition in the financial management of companies. The newest one is paper (Devos and Li, 2020). The author of this paper investigated whether management of firms recognizes hedging opportunities of operating leases by examining the relationship between chief executive officer risk-taking incentives and the use of operating leases.

Another sphere of research is green leasing and leasing of places of extraction of natural resources. The oldest research in this area referred in Scopus is paper (Andrus and Turcott, 1974). This work represented a brief expose of mineral leasing in federally-owned land by a Bureau of Land Management, change and improvement in legislation, that are necessary to keep up with increasing public demand for resources from, and use of public lands for all type resources, especially in the energy field. Among recent paper, the article (Ballardini et al., 2020.) presents specific issues related to acts of leasing, wherein private law fields (intellectual property and property laws) are currently failing to provide the incentives needed for directing innovations and businesses towards more sustainable types of model. The author of the oldest paper indexed WoS (Santini, 1979) commented on coal leasing in the light of concern with a deficiency in available reserves, the balance between energy demand and ability to plan for production and environmental safeguards. The latest paper (Yang et al., 2020) focused on two areas of research. Herewith, the first area is to compare green leasing guidelines from various countries and to suggest comprehensive categories of green leasing components. In contrast, the second area analyzed government tenanted properties' lease agreement contracts. The next area of publications is connected with using the leasing as a financial tool in the innovative company and tools and software of serving the leasing contracts. The first work (Dennis, 1968) dedicated to the role of leasing in the effective operation of the information service industry through a clear separation among costs for computing, communications, and the development of information services. Moreover, this article considered the wide use of multiaccess system concepts. Thus, the information services may share in the use of computer installations, and so their cost of construction is reasonable. The latest paper (Berdeddouch et al., 2020) devoted to autonomous cars as a point of sending, receiving and analyzing big data and using of this information by many stakeholders (road authorities, leasing companies, municipalities, car manufacturers, insurers, workshops, emergency services, etc.) in the mobility space to improve processes. According to WoS, the oldest article (Forgionne, 1997) described the gaps, benefits, challenges, and limitations. Besides it shows how a decision technology system, called the Housing Analysis Decision Technology System, could help 
Army managers to make the construction and/or leasing decisions. Among recent articles, the study (Nechaev et al., 2020) noted the importance of methodologies of improving the efficiency of innovative leasing-based companies since the leasing form of financing is significant in updating the fixed assets of small and medium enterprises. The findings deduced that despite big number researches about the innovation in leasing or leasing of innovation from many perspectives, out of focus of them remained the impact of the leasing on taxation, money laundry, offshore leasing etc. Therefore, the goal of this article is to examine the tendency in the scientific publications on the leasing of the innovations and innovations in leasing to define prospective research directions.

Methodology. The idea of this paper is to verify the scientific trend on analyzing the innovation in leasing or leasing of innovation problems. To rich this purpose, it was decided to use the research algorithm proposed by (Vasylieva et al., 2020):

1. To investigate the quantity tendency of the researches devoted to the analyses of the leasing of the innovations and innovations in leasing issues.

2. To position the basic subject areas of investigations in the leasing of the innovations and innovations in leasing issues.

3. To define the most cited papers and scientific journals published the papers on the innovation in leasing or leasing of innovations.

4. To cluster the scientific background on the principal vectors of researches to determine the further directions for investigation in areas of innovation in leasing or leasing of innovations.

For selecting the publications to forthcome analyze, the following keywords were chosen: innovation, leasing, leasing management, innovation in leasing. The study sample is 2513 papers from Scopus (1915) and Web of Science (598). The study period is from 1950 to present for the Scopus database and from 1970 to present for WoS. The research was conducted using the software VOSviewer, as well as WoS and Scopus databases. Besides, Scopus and WoS databases give the possibility to decompose the papers in various variables such as a number of the papers, the subject area, country affiliation, source, citation etc. In turn, VOSviewer (module «network visualization») allows positioning and visualizing the connections of keywords which mentioned in the papers and co-cited in different researches in the sphere of the innovation in leasing or leasing of innovations. Furthermore, it is possible to define the scientific directions with strong correlations between the terminology of papers. That based on the assertion in the user manual, where state that the «closer» keywords are located to each other, the «stronger» their links in decomposition.

Results. The findings of this research show that the numbers of publications devoted to the innovation in leasing or leasing of innovations in the database Scopus were growing at a variable rate throughout the analyzed period. In turn, a considerable rising of papers occurred from 2000 to 2010 (average growth rate of $13,8 \%$ ). The numbers of paper in journals indexed by WoS had a growing tendency during the analyzed time. The rate of growth was $19,9 \%$. Thus, this database shows a significant growth rate of publications from 2010 to 2019. That may be acquitted by the discussions on the problems of active implementation of digital technologies in finance, developing fintech, big data analyze etc. In 2019 , in the WoS database, the number of papers devoted to the innovation in leasing or leasing of innovations raised by $412 \%$ compared to 2010 (figure 2). The results demonstrate that the innovation in leasing or leasing of innovations was in the focus of scientific journals indexed by Scopus database. It stands to mention that they are positioned in the subject areas as follows: Medicine - 18.41\%; Engineering - 14.95\%; Social Sciences - 9.02\%; Environmental Science - 8.95\%; Business, Management and Accounting - 8.41\%; Computer Science 7.32 and others (Economics, Econometrics and Finance, Agricultural and Biological Sciences, etc. - 21 areas) $-32.95 \%$. 


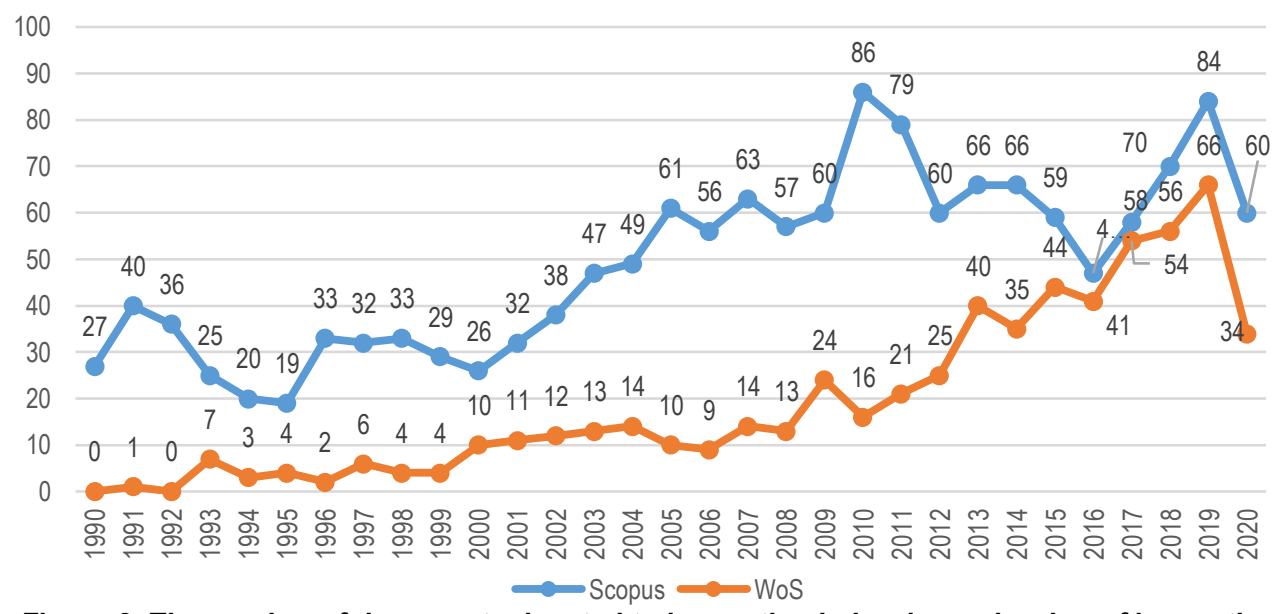

Figure 2. The number of documents devoted to innovation in leasing or leasing of innovation indexed in Scopus and WoS databases

Sources: developed by the author using data from Scopus and WoS.

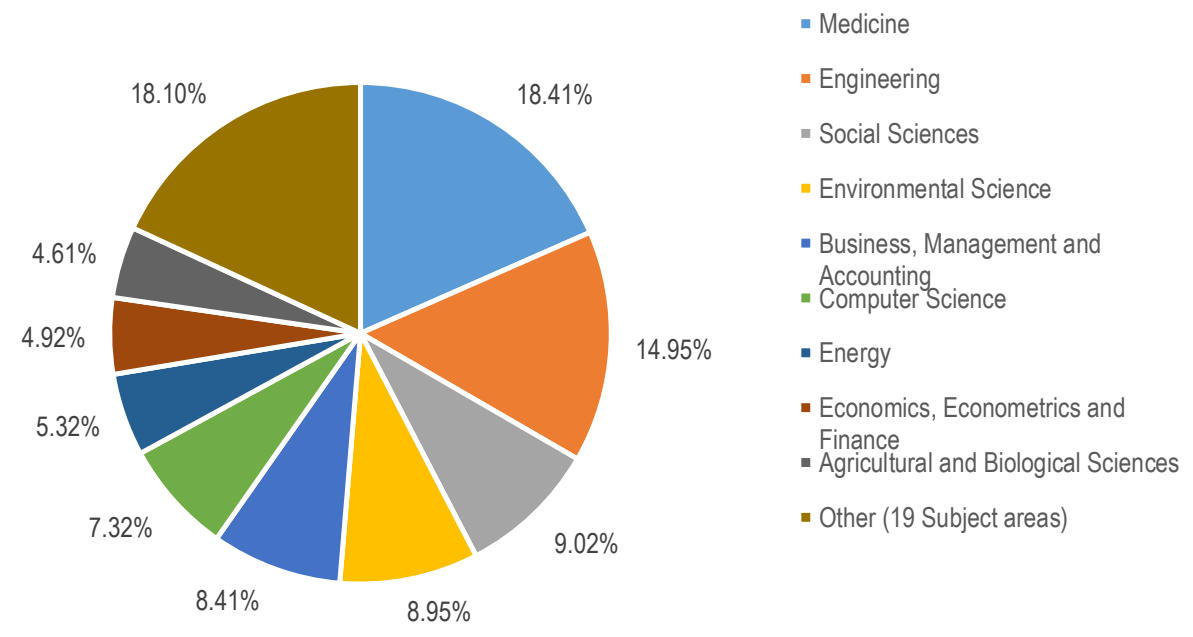

Figure 3. Investigation the issue of innovation in leasing or leasing of innovation by subject areas in the Scopus database

Sources: developed by the author using data from Scopus.

In turn, in WoS database the scientific journals, which published the papers devoted to the innovation in leasing or leasing of innovations, allocated in the subject areas as follows: Business Economics- $15.0 \%$; Engineering - 14.3\%; Environmental sciences ecology - 10.0\%; Computer science - 9.5\%; Operations research management science $-5.5 \%$; Telecommunications $-5.1 \%$; Agriculture $-3.0 \%$ and others 66 Research areas with share $<1 \%)-37.6 \%$. Grouping the investigated papers by countries demonstrated that the most scientists interested in the investigation of the innovation in leasing or leasing of innovations issues have the affiliations of the countries such as USA, China, United Kingdom and Germany. 


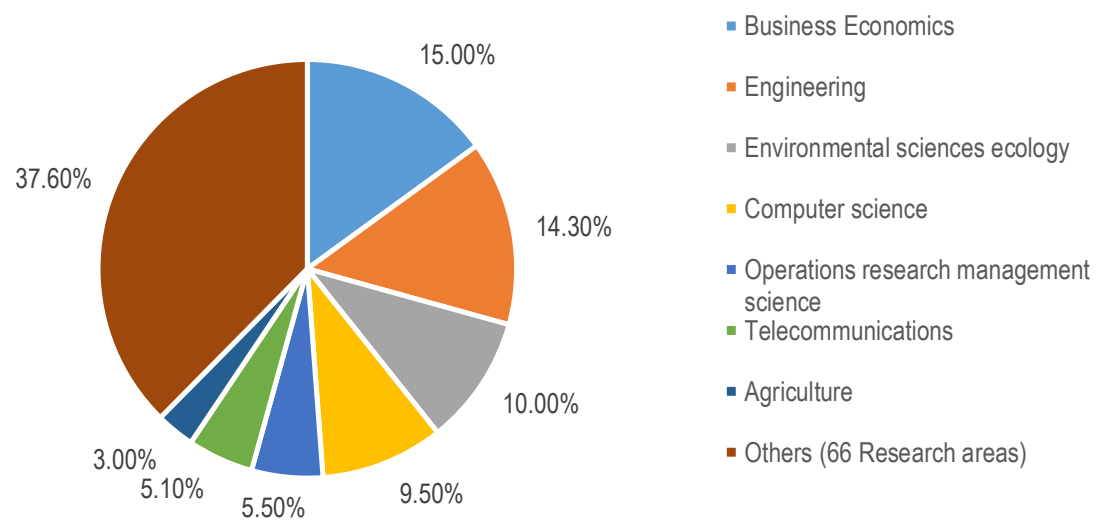

Figure 4. Investigation the issue of innovation in leasing or leasing of innovation by subject areas in the WoS database

Sources: developed by the author using data from Web of Science database.

Figure 5 shows the top-20 affiliations of scientists by countries based on the Scopus data, as well as the number of articles presented by these countries in the WoS database.

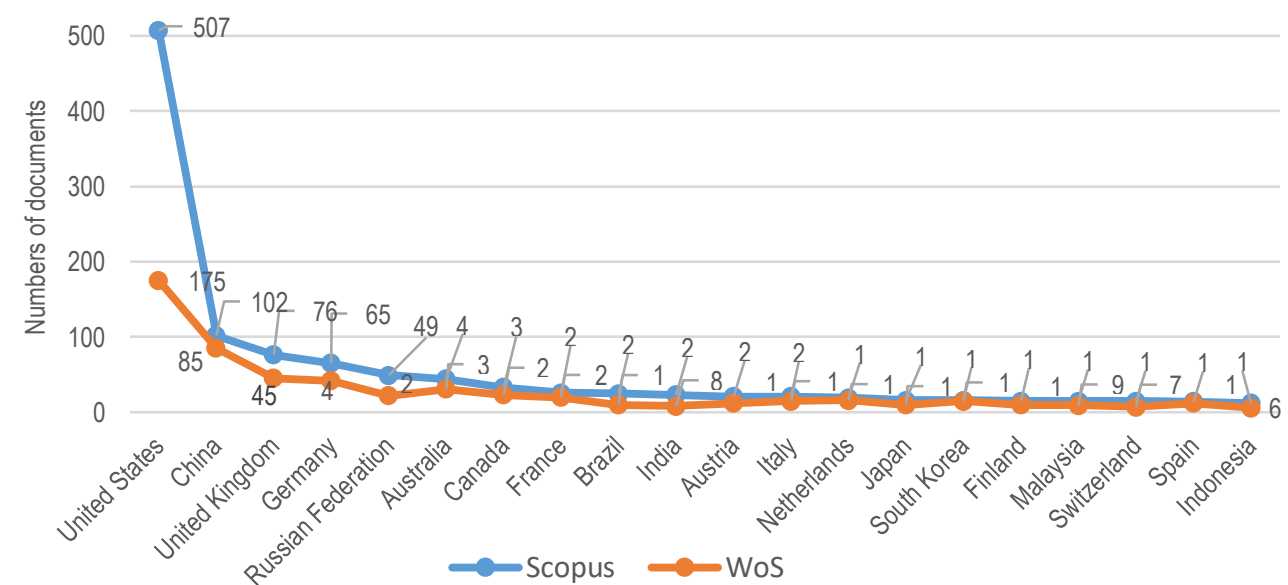

Figure 5. Top-20 affiliations of the scientists investigated the innovation in leasing or leasing of innovation issues (by countries)

Sources: developed by the author using data from WoS and Scopus.

Moreover, considering the results from Scopus analyses for 2019, the scientific journals with high impact factor (Land Use Policy, European Journal of Operational Research, Ecology and Society) published papers in areas of the innovation in leasing or leasing of innovations issues. However, the biggest number of paper was published in low- and middle-rank journals (Table 1).

There is another situation with paper in the WoS database. Thus, 3 of 5 journals published articles dedicated to the innovation in leasing or leasing of innovation issues are high ranking journals (Table 2). 
Table 1. The top-5 scientific journals which published the biggest number of papers on the innovation in leasing or leasing of innovation issues (by Scopus)

\begin{tabular}{|c|c|c|c|c|c|c|}
\hline Title of the Journal & Covered period & Subject area & $\begin{array}{l}\text { Cite } \\
\text { Score }\end{array}$ & $\begin{array}{l}\text { SJR } \\
2019\end{array}$ & $\begin{array}{l}\text { SNIP } \\
2019\end{array}$ & $\begin{array}{c}\text { Numbers of } \\
\text { the papers }\end{array}$ \\
\hline Modern Healthcare & from 1975 to 2016 & $\begin{array}{l}\text { Medicine: General } \\
\text { Medicine } \\
\text { Energy: Energy }\end{array}$ & $\begin{array}{c}0.1 \\
(2017)\end{array}$ & 0.107 & - & 55 \\
\hline Oil and Gas Journal & $\begin{array}{l}\text { 1966, from } 1969 \text { to } \\
2014,2017\end{array}$ & $\begin{array}{c}\text { Engineering and Power } \\
\text { Technology } \\
\text { Energy: Fuel } \\
\text { Technology }\end{array}$ & $\begin{array}{c}0.101 \\
(2015)\end{array}$ & 0.101 & $\begin{array}{l}0.091 \\
(2017)\end{array}$ & 43 \\
\hline $\begin{array}{l}\text { Healthcare Financial } \\
\text { Management }\end{array}$ & from 1982 to 2016 & $\begin{array}{l}\text { Medicine: General } \\
\text { Medicine }\end{array}$ & $\begin{array}{c}0.3 \\
(2017)\end{array}$ & 0.132 & $\begin{array}{c}0.314 \\
(2016)\end{array}$ & 26 \\
\hline Hospitals & from 1945 to 1993 & $\begin{array}{l}\text { Nursing: Leadership and } \\
\text { Management }\end{array}$ & - & - & - & 21 \\
\hline $\begin{array}{l}\text { Dental economics - } \\
\text { oral hygiene }\end{array}$ & from 1968 to 1999 & $\begin{array}{l}\text { Medicine: General } \\
\text { Medicine }\end{array}$ & - & $\begin{array}{l}0.102 \\
(2002)\end{array}$ & - & 20 \\
\hline
\end{tabular}

Sources: developed by the author using data from Scopus.

Table 2. The top-5 scientific journals published the papers on the shadow economy (by WoS)

\begin{tabular}{ccccc}
\hline $\begin{array}{c}\text { Title of the } \\
\text { Journal }\end{array}$ & H Index & Subject Area: Category & $\begin{array}{c}\text { SJR } \\
\text { 2019 }\end{array}$ & $\begin{array}{c}\text { Quartile in Numbers of } \\
\text { Category }\end{array}$ \\
\hline the papers
\end{tabular}

Source: developed by the author using data from ScimagoJR and WoS. 
Table 3 shows that 6 out of 10 the most cited papers in Scopus database were issued for the public by the scientific journals with high impact factor (SNIP>1). Besides, the most cited paper is the article by the scientists such as Loomis, J., Kent, P., Strange, L., Fausch, K., and Covich, A. (Loomis et al., 2000). This article was published in Ecological Economics in 2000. In 2006, a famous expert of Amazon.com, Inc., Laura E. Grit, with her colleagues published the proceeding «Sharing networked resources with brokered leases» (Irwin et al., 2006). It stands to mention that this paper focused on the design and implementation of Shirako, which is a system for «on-demand leasing of shared networked resources». In turn, the study has been cited 114 times. Besides, the paper (Grit et al., 2006) cited 106 times, investigated the questions of resource management policy and orchestration of this system (Table 3).

Table 3. The most cited papers devoted to the issues of the innovation in leasing or leasing of innovation in the Scopus database, 1950-2020

\begin{tabular}{|c|c|c|c|}
\hline $\begin{array}{ll}\text { Authors and Title } \\
\end{array}$ & Year & Source title & Cited \\
\hline $\begin{array}{l}\text { Loomis, J., Kent, P., Strange, L., Fausch, K., \& Covich, } \\
\text { A. Measuring the total economic value of restoring } \\
\text { ecosystem services in an impaired river basin: Results } \\
\text { from a contingent valuation survey. }\end{array}$ & 2000 & Ecological Economics & 473 \\
\hline $\begin{array}{l}\text { Palmer, M. A., Lettenmaier, D. P., Poff, N. L., Postel, S. } \\
\text { L., Richter, B., \& Warner, R. Climate change and river } \\
\text { ecosystems: Protection and adaptation options. } \\
\text { Pinkerton. E \& Edwards. D N. The elephant in the }\end{array}$ & 2009 & Environmental Management & 226 \\
\hline $\begin{array}{c}\text { room: The hidden costs of leasing individual transferable } \\
\text { fishing quotas. }\end{array}$ & 2009 & Marine Policy & 159 \\
\hline $\begin{array}{l}\text { Sotomayor, B., Keahey, K., \& Foster, I. (). Combining } \\
\text { batch execution and leasing using virtual machines. }\end{array}$ & 2008 & $\begin{array}{l}\text { Proceedings of the 17th } \\
\text { International Symposium on High } \\
\text { Performance Distributed } \\
\text { Computing, 2008, HPDC'08 }\end{array}$ & 157 \\
\hline $\begin{array}{l}\text { Desai, P., \& Purohit, D. Leasing and selling: Optimal } \\
\text { marketing strategies for a durable goods firm. }\end{array}$ & 1998 & Management Science & 139 \\
\hline $\begin{array}{c}\text { Agrawal, V. V., Ferguson, M., Toktay, L. B., \& Thomas, } \\
\text { V. M. Is leasing greener than selling? }\end{array}$ & 2012 & Management Science & 130 \\
\hline $\begin{array}{c}\text { Irwin, D., Chase, J., Grit, L., Yumerefendi, A., Becker, } \\
\text { D., \& Yocum, K. G. Sharing networked resources with } \\
\text { brokered leases. }\end{array}$ & 2006 & $\begin{array}{l}\text { USENIX } 2006 \text { Annual Technical } \\
\text { Conferenc }\end{array}$ & 114 \\
\hline $\begin{array}{l}\text { Auerbach, A. J. Chapter } 19 \text { taxation and corporate } \\
\text { financial policy. }\end{array}$ & 2002 & Handbook of Public Economics & 108 \\
\hline $\begin{array}{l}\text { Grit, L., Irwin, D., Yumerefendi, A., \& Chase, J. Virtual } \\
\text { machine hosting for networked clusters: Building the } \\
\text { foundations for "autonomic" orchestration. }\end{array}$ & 2006 & $\begin{array}{c}\text { VTDC } 2006 \text { - 2nd International } \\
\text { Workshop on Virtualization } \\
\text { Technology in Distributed } \\
\text { Computing; Held in Conjunction } \\
\text { with SC06 }\end{array}$ & 106 \\
\hline $\begin{array}{l}\text { Thompson, M., \& Homewood, K. Entrepreneurs, elites, } \\
\text { and exclusion in Maasai land: Trends in wildlife } \\
\text { conservation and pastoralist development }\end{array}$ & 2002 & Human Ecology & 105 \\
\hline
\end{tabular}

The findings of the WoS analysis differ from the mentioned above. Thus, 9 out of 10 most cited papers were issued for the public in the scientific journals of top of rank. In 2012, the expert of European Commission Joint Research Centre, Francesco Pantisano, with his colleges published the paper «Spectrum leasing as an incentive towards uplink macrocell and femtocell cooperation» (Pantisano. et al., 
2012). The authors focused on the formulation of conditions coalitional game and demonstrated that the network could self-organize. It stands to mention that this study was cited 83 times. Therefore, it is the one of the most cited papers in the field of the innovation in leasing or leasing of innovation issues according to WoS.

Table 4. The most cited papers devoted to the issues of the innovation in leasing or leasing of innovation issues in the WoS database, 1970-2020

\begin{tabular}{|c|c|c|c|}
\hline $\begin{array}{l}\text { Authors and Title } \\
\end{array}$ & Year & Source title & Cited \\
\hline $\begin{array}{l}\text { Palmer, M. A., Lettenmaier, D. P., Poff, N. L., Postel, S. } \\
\text { L., Richter, B., \& Warner, R. Climate change and river } \\
\text { ecosystems: Protection and adaptation options. }\end{array}$ & 2009 & $\begin{array}{l}\text { Environmental } \\
\text { Management }\end{array}$ & 206 \\
\hline $\begin{array}{l}\text { Pinkerton, E., \& Edwards, D. N. The elephant in the } \\
\text { room: The hidden costs of leasing individual transferable } \\
\text { fishing quotas }\end{array}$ & 2009 & Marine Policy & 158 \\
\hline $\begin{array}{c}\text { Waldman, M. Durable goods theory for real world } \\
\text { markets. }\end{array}$ & 2003 & $\begin{array}{c}\text { Journal of Economic } \\
\text { Perspectives }\end{array}$ & 137 \\
\hline $\begin{array}{l}\text { Pantisano, F., Bennis, M., Saad, W., \& Debbah, M. } \\
\text { Spectrum leasing as an incentive towards uplink } \\
\text { macrocell and femtocell cooperation. }\end{array}$ & 2012 & $\begin{array}{l}\text { IEEE Journal on Selected } \\
\text { Areas in Communications, }\end{array}$ & 83 \\
\hline $\begin{array}{c}\text { Fabiano, B., Currò, F., Reverberi, A. P., \& Pastorino, R. A } \\
\text { statistical study on temporary work and occupational } \\
\text { accidents: Specific risk factors and risk management } \\
\text { strategies. }\end{array}$ & 2008 & Safety Science & 77 \\
\hline $\begin{array}{l}\text { Pierce, L. (). Big losses in ecosystem niches: How core } \\
\text { firm decisions drive complementary product shakeouts. }\end{array}$ & 2009 & $\begin{array}{l}\text { Strategic Management } \\
\text { Journal }\end{array}$ & 72 \\
\hline $\begin{array}{l}\text { Craig, J., Halls, A., Barr, J., Bean, C. } \\
\text { The Bangladesh floodplain fisheries. }\end{array}$ & 2004 & Fisheries Research & 72 \\
\hline $\begin{array}{c}\text { Rampini, A., Viswanathan, S. Collateral and capital } \\
\text { structure. }\end{array}$ & 2013 & $\begin{array}{l}\text { Journal of Financial } \\
\text { Economics }\end{array}$ & 71 \\
\hline $\begin{array}{c}\text { Brax, S. A., \& Visintin, F. Meta-model of servitization: The } \\
\text { integrative profiling approach. }\end{array}$ & 2017 & $\begin{array}{l}\text { Industrial Marketing } \\
\text { Management }\end{array}$ & 64 \\
\hline $\begin{array}{l}\text { Allen, D. K., Colligan, D., Finnie, A., \& Kern, T. Trust, } \\
\text { power and interorganizational information systems: The } \\
\text { case of the electronic trading community TransLease. }\end{array}$ & 2000 & $\begin{array}{l}\text { Information Systems } \\
\text { Journal }\end{array}$ & 63 \\
\hline
\end{tabular}

Sources: developed by the author using data from WoS.

Scopus and WoS tools allow identifying the authors with the greatest publication activity. Based on the Scopus database, one of the most active authors in the investigated area is Thomas Jakl, who is an expert of Chemicals Policy Directorate Federal Ministry for Agriculture, Regions and Tourism (Vienna, Austria). The author published 8 papers on the innovation in leasing or leasing of innovation issues, which are indexed by the Scopus database (Table 5).

In turn, according to WoS database, the most active author is Frank Moser, who is a programme officer at the Secretariat of the Basel, Rotterdam and Stockholm Conventions United Nations Environment Programme (Basel, Switzerland, 2009-present), Industrial Development Officer UNIDO and Associate Programme officer of United Nations Environmental Programme (Nairobi, Kenya, 2005-2007). This author published 6 papers on the innovation in leasing or leasing of innovation issues, which are indexed by WoS (Table 6). The VOSviewer bibliographic tool allowed identifying 6 clusters of the papers which investigated the issues of innovation in leasing or leasing of innovation from the different points of views (Figure 6). 
Table 5. Top-5 most publishing authors publishing on the innovation in leasing or leasing of innovation issues according to Scopus database, 1950-2020

\begin{tabular}{|c|c|c|c|c|}
\hline Authors & Affiliation & Subject Areas & $h$-index & $\begin{array}{l}\text { Number of } \\
\text { documents }\end{array}$ \\
\hline Snow, Nick & - & $\begin{array}{l}\text { Energy, Mathematics, } \\
\text { Environmental Science }\end{array}$ & 3 & 34 \\
\hline Jakl, Thomas & $\begin{array}{c}\text { Federal Ministry for } \\
\text { Agriculture, Regions } \\
\text { and Tourism, Vienna, } \\
\text { Austria }\end{array}$ & $\begin{array}{l}\text { Environmental Science, Medicine, Earth and } \\
\text { Planetary Sciences, Chemical Engineering, Energy }\end{array}$ & 4 & 8 \\
\hline $\begin{array}{l}\text { Forgionne, } \\
\text { Guisseppi A. }\end{array}$ & $\begin{array}{l}\text { University of Maryland, } \\
\text { Baltimore County, } \\
\text { Baltimore, United } \\
\text { States }\end{array}$ & $\begin{array}{c}\text { Computer Science, Business, Management and } \\
\text { Accounting, Decision Sciences, Mathematics, } \\
\text { Social Sciences, Engineering, Medicine, Health } \\
\text { Professions, Economics, Econometrics and } \\
\text { Finance, Biochemistry, Genetics and Molecular } \\
\text { Biology, Nursing, Arts and Humanities, Dentistry, } \\
\text { Earth and Planetary Sciences }\end{array}$ & 15 & 6 \\
\hline $\begin{array}{l}\text { Edwards, } \\
\text { Danielle N. }\end{array}$ & $\begin{array}{l}\text { The University of } \\
\text { British Columbia, } \\
\text { Vancouver, Canada }\end{array}$ & $\begin{array}{l}\text { Environmental Science, Agricultural and Biological } \\
\text { Sciences, Social Sciences, Economics, } \\
\text { Econometrics and Finance, Multidisciplinary }\end{array}$ & 3 & 5 \\
\hline Lutz, S. & - & Medicine & 6 & 5 \\
\hline
\end{tabular}

Sources: developed by the author using data from Scopus.

Table 6. Top-5 most publishing authors on the innovation in leasing or leasing of innovation issues according to WoS database, 1970-2020

\begin{tabular}{|c|c|c|c|c|}
\hline Authors & Affiliation & Web of Science Categories & h-index & $\begin{array}{l}\text { Number of } \\
\text { documents }\end{array}$ \\
\hline Moser, Frank & $\begin{array}{c}\text { United Nations } \\
\text { Environmental } \\
\text { Programme, Secretariat } \\
\text { Basel Rotterdam \& } \\
\text { Stockholm Convent, } \\
\text { Basel, Switzerland }\end{array}$ & $\begin{array}{c}\text { Environmental Sciences, } \\
\text { Mathematics Interdisciplinary } \\
\text { Applications, Public Environmental } \\
\text { Occupational Health, } \\
\text { Social Sciences Mathematical } \\
\text { Methods, Toxicology }\end{array}$ & 11 & 6 \\
\hline $\begin{array}{l}\text { Song, } \\
\text { Dongping }\end{array}$ & $\begin{array}{l}\text { University of Liverpool } \\
\text { Management School, } \\
\text { Liverpool, Merseyside, } \\
\text { England }\end{array}$ & $\begin{array}{c}\text { Management, Operations Research } \\
\text { Management Science, Automation } \\
\text { Control Systems, Engineering } \\
\text { Electrical Electronic, }\end{array}$ & 22 & 6 \\
\hline $\begin{array}{l}\text { Edwards, } \\
\text { Danielle N. }\end{array}$ & $\begin{array}{c}\text { University of Kentucky, } \\
\text { Sanders Brown Center } \\
\text { Aging, Lexington, KY, USA } \\
\text { Aristotle University of }\end{array}$ & $\begin{array}{l}\text { Environmental Studies, International } \\
\text { Relations, Ecology }\end{array}$ & 6 & 5 \\
\hline $\begin{array}{l}\text { Karatza, } \\
\text { Eleni }\end{array}$ & $\begin{array}{c}\text { Thessaloniki, Department } \\
\text { Informatization, } \\
\text { Thessaloniki, Greece }\end{array}$ & Business, Telecommunications & 1 & 5 \\
\hline $\begin{array}{l}\text { Pinkerton, } \\
\text { Evelyn }\end{array}$ & $\begin{array}{c}\text { Canadian Fisheries } \\
\text { Research Network, School } \\
\text { Resource \& Environment } \\
\text { Management, ST } \\
\text { Andrews, NB, Canada }\end{array}$ & $\begin{array}{l}\text { Environmental Studies, International } \\
\text { Relations, Ecology }\end{array}$ & 17 & 5 \\
\hline
\end{tabular}

Sources: developed by the author using data from WoS. 


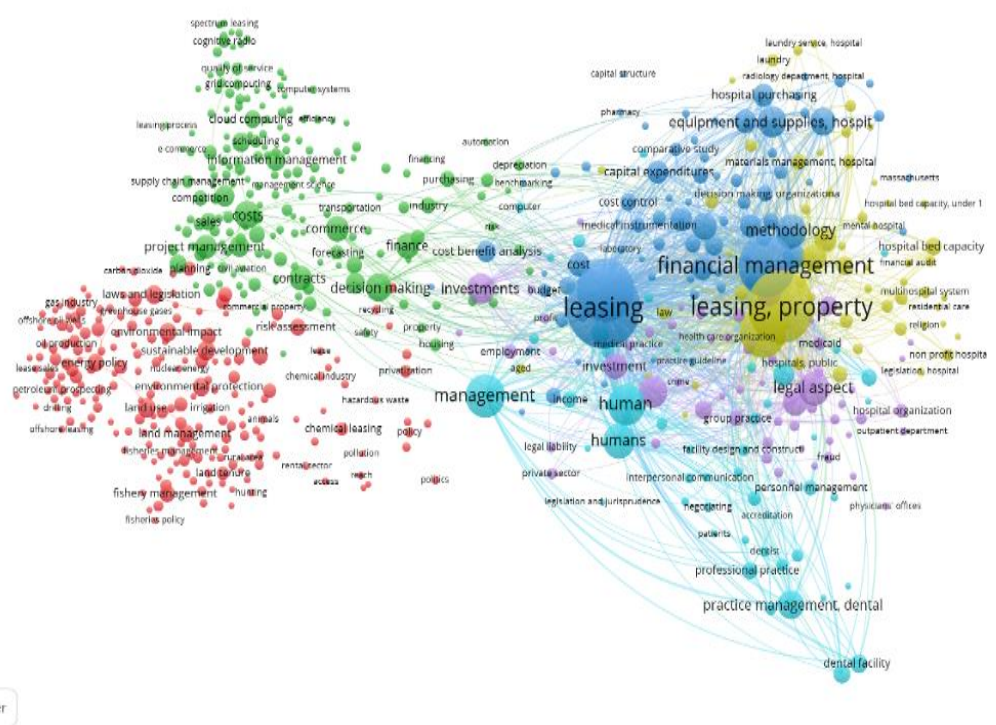

Figure 6. The network visualization of the co-citation of the papers on the issues of innovation in leasing or leasing of innovation

Sources: developed by the author on the basis of Scopus and WoS using VOSviewer tool.

The first biggest cluster (red cluster - 209 items) covers the documents indexed by the keywords such as sustainable development, environmental impact, environmental protection, energy policy, land use, land management, fishery management, laws and legislation, risk assessment etc. (Figure 7).

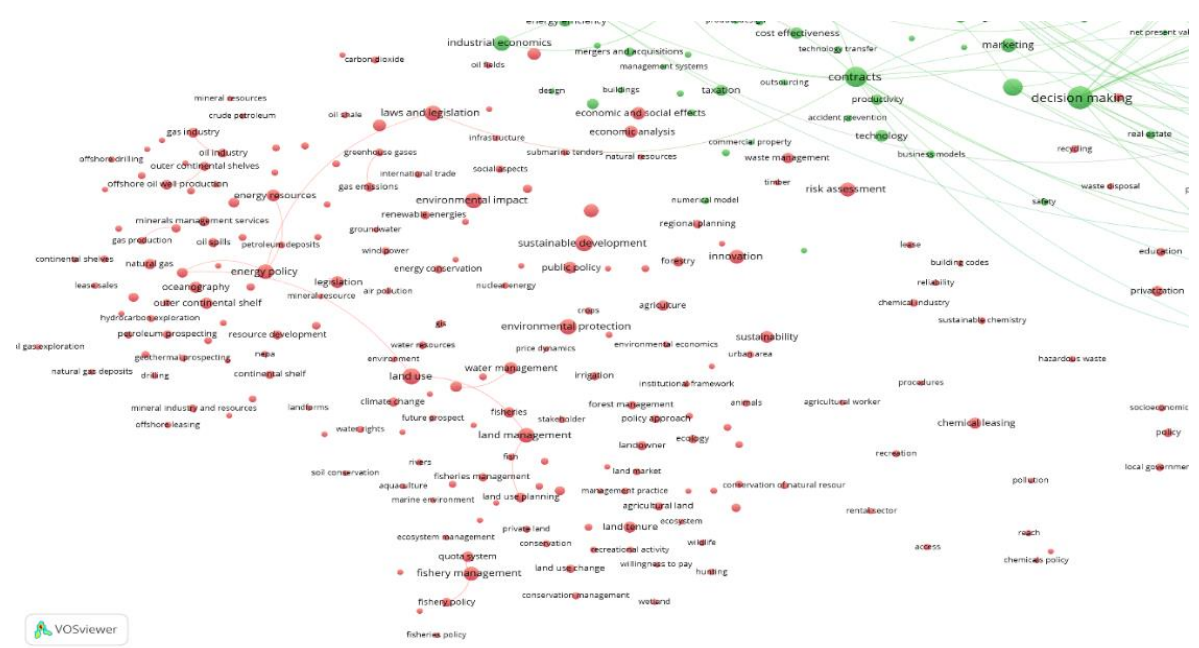

Figure 7. The network visualization of the co-citation of the keywords on the innovation in leasing or leasing of innovation issues with close areas (the biggest red cluster)

Sources: developed by the author on the basis of Scopus and WoS using VOSviewer tool. 
In turn, it confirms the stated fact of the existence of a separate area of research on the leasing and innovation - the issues of leasing land, forests, sources of natural resources, permits for their use. The second cluster (green cluster - 189 items) covers the sphere of information system and software in leasing management. This cluster formulated with the documents indexed by the keywords such as decision making, costs, project management, contracts, finance, commerce, information management, resource allocation, cloud computing etc. (Figure 8).

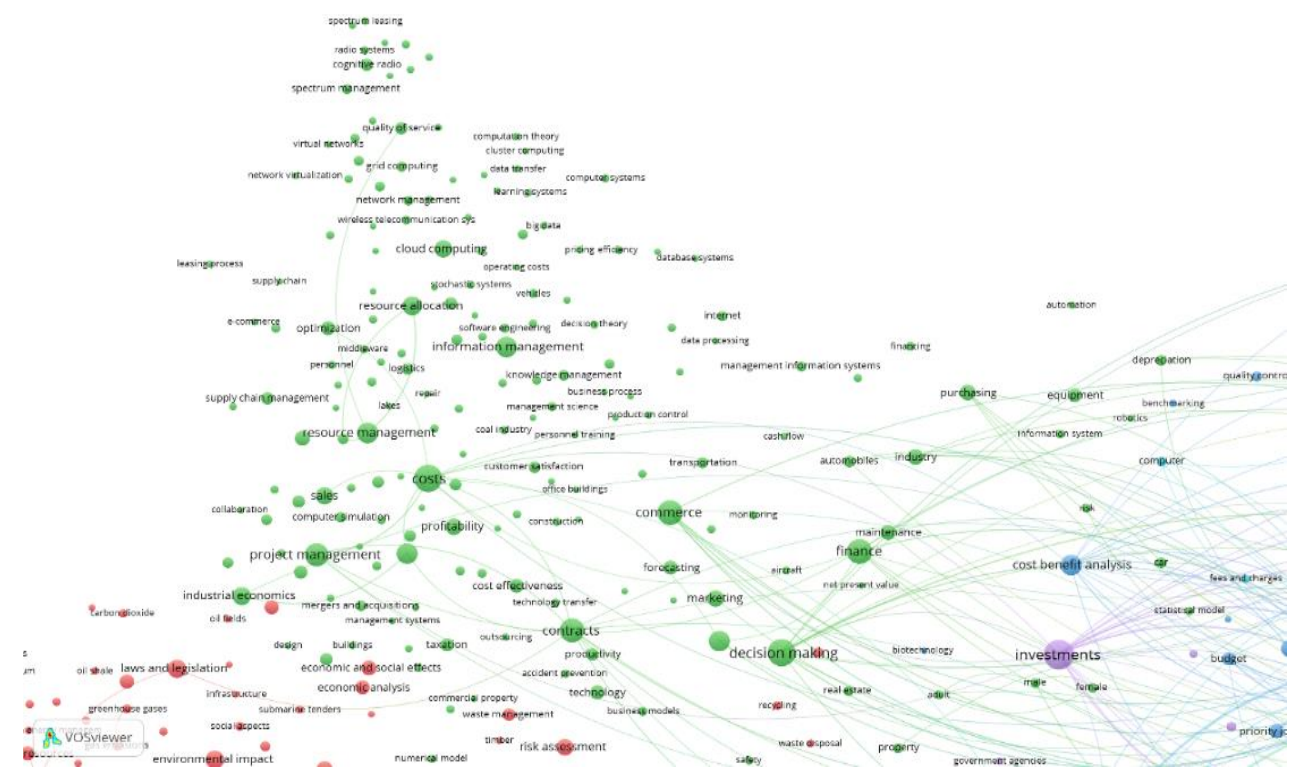

Figure 8. The network visualization of the co-citation of on the innovation in leasing or leasing of innovation issues with close areas (green cluster)

Sources: developed by the author on the basis of Scopus and WoS using VOSviewer tool.

The third cluster (blue cluster - 78 items) focused on the issues such as leasing, economics, financial management, equipment and supplies, capital expenditures, economic aspects, cost control, cost and cost analyze, cost-benefit analyze etc. Figure 9 shows that it is close to the similar yellow and purple clusters. The fourth cluster (yellow - 59 items) consists of the studies indexed by the keywords as follows: leasing property, organization and management, hospital management, hospital, hospital bad capacity etc. Thus, it confirms the stated in the literature review fact of the existence of a separate area of research on leasing and innovation (leasing in health management).

Next cluster (purple - 59 items) includes keywords such as ownership, investment, legal aspects, capital financing, health care facility etc. In turn, the third, fourth and fifth clusters are correlated by the keywords «leasing - legal aspect - health care/medical practice management - hospital equipment/hospital information system», etc. Based on the VOSviewer manual, the tighter location of the mentioned clusters, the more intensive their relations. The findings proved that the leasing of medical equipment is a considerable aspect of health and hospital management. Besides, it remains popular in investigations of the great string of the scientists (Figure 9). 


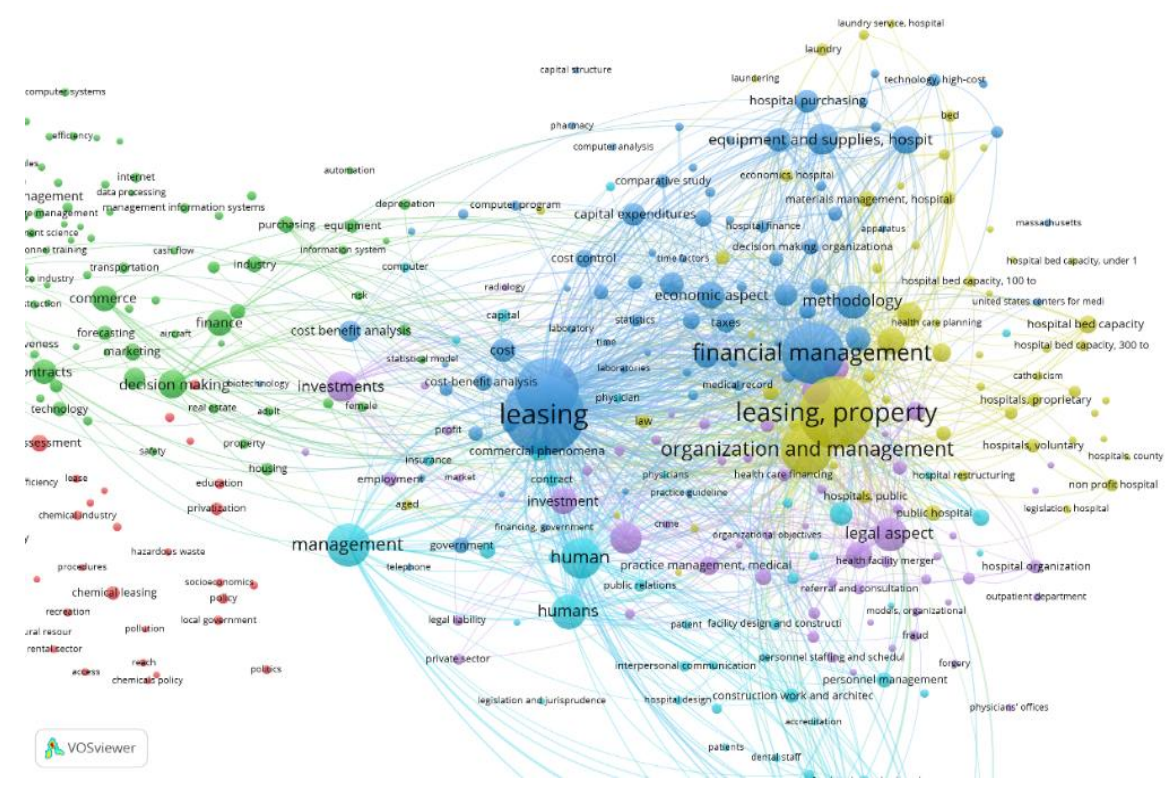

Figure 9. The network visualization of the co-citation of the keywords on blue, yellow and purple clusters

Sources: developed by the author on the basis of Scopus and WoS database using VOSviewer tool.

Figure 10 demonstrates that the smallest cluster (turquoise - 49 items) focused on the issues such as human (s), management, practice management, dental, dental facilities, personal management etc.

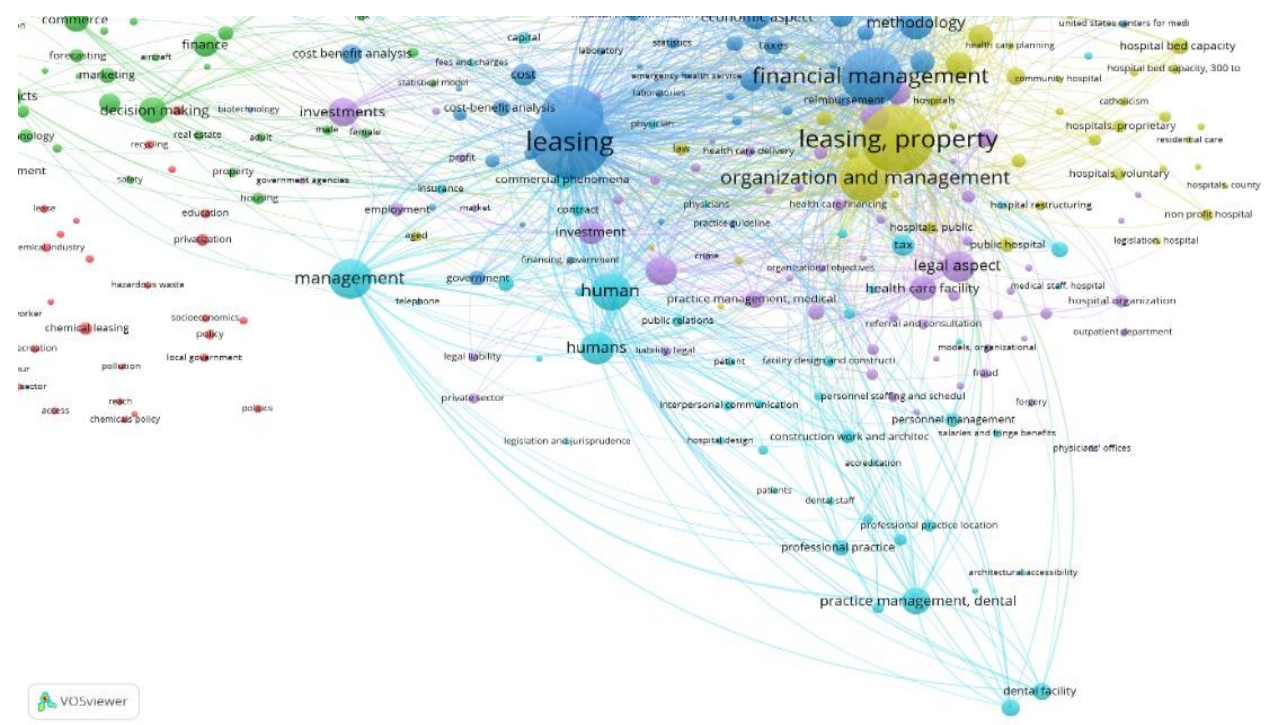

Figure 10. The network visualization of the co-citation of the keywords on the innovation in leasing or leasing of innovation issues on the turquoise cluster

Sources: developed by the author on the basis of Scopus and WoS database using VOSviewer tool. 
Figure 11 demonstrates the detailed analysis of the co-citations on the issues of innovation in leasing or leasing of innovation in third, fourth and fifth clusters. The keywords are as follows: financial management, taxes, capital financing, leasing - property, capital expenditure, accounting, legal aspect, management and tax. Figure 11 shows the findings, which confirm the research hypothesis that the topic of taxation and its role in financial and operation management is very popular in the papers focused on the issues of innovation in leasing or leasing of innovation.

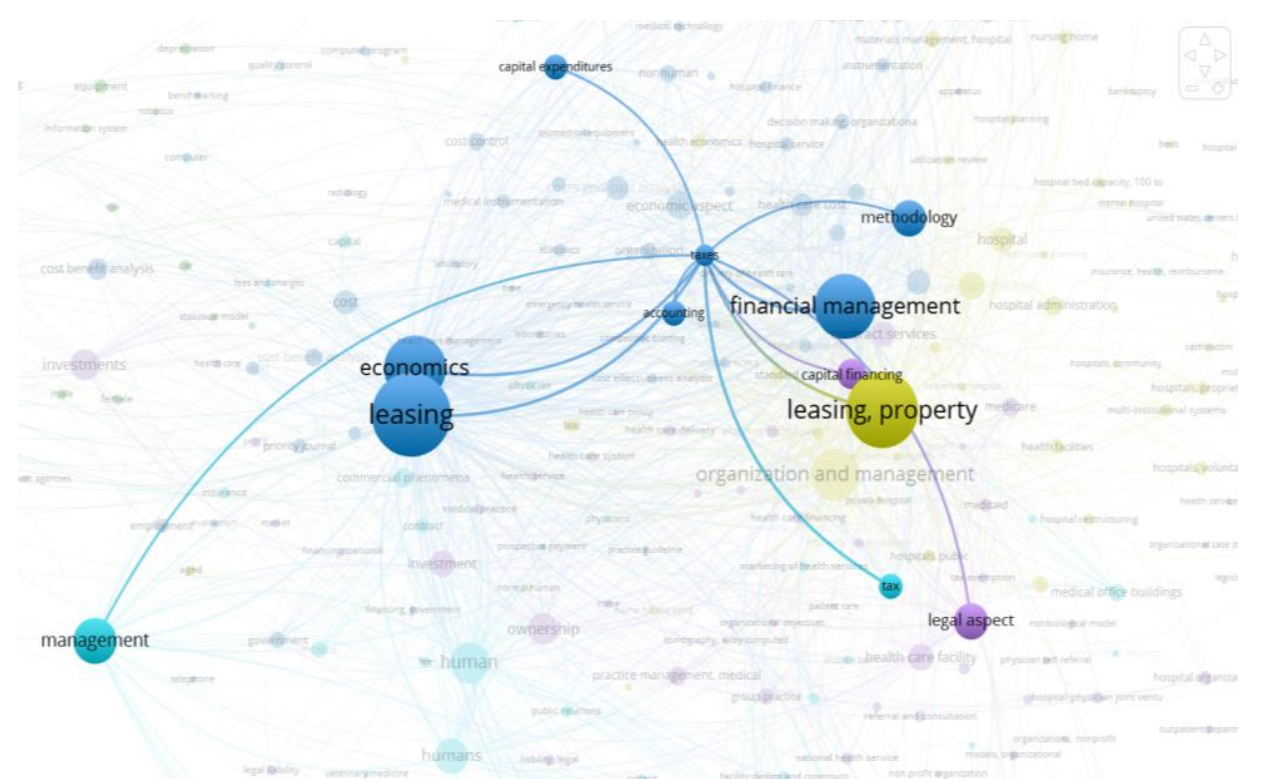

Figure 11. The network visualization of the keywords co-citation of 3-6 clusters

Sources: developed by the author on the basis of Scopus and WoS database using VOSviewer tool.

Therefore, the findings indicate that the red and green clusters were biggest. In turn, the red cluster based on papers dedicated to researching on the leasing and innovation (issues of leasing land, forests, sources of natural resources and permits for their use). It stands to mention that the topic of leasing innovations and innovations in leasing is very popular among medical journals devoted to health care management and the issues of efficient receipt and use of equipment, premises, etc.

Conclusion. The obtained results proved that the issues on leasing innovations and innovations in leasing are a sought-after direction for research, which set up different scientific direction. Besides, the number of papers in Scopus database had a growing tendency with a variable rate. Note, a significant increase in the number of securities that occurred from 2000 to 2010. In turn, the number of paper in journals indexed by WoS had been regular rising during the analyzed period with a growth rate of $19,9 \%$. Thus, this database shows a considerable growth of publications from 2010 to 2019 . The findings by VOSviewer analysis allowed identifying six clusters. It worth to mention that three out of six clusters have a close connection. Thus, the first biggest cluster built on the keywords as follows: sustainable development, environmental impact, environmental protection, energy policy, land use, land management, fishery management, laws and legislation, risk assessment etc. In turn, the second cluster indicated on the investigations in the sphere of information system and software in leasing. Three clusters (the third, fourth and fifth) are connected by the words «leasing - legal aspect - health care/medical practice management - hospital equipment/hospital information system», etc. The findings proved that the leasing 
of medical equipment is a considerable aspect of health and hospital management. Therefore, it remains popular in investigations of the great string of the scientists in the area of the leasing of innovations and innovations in leasing.

\section{References}

Agrawal, V. V., Ferguson, M., Toktay, L. B., \& Thomas, V. M. (2012). Is leasing greener than selling?. Management Science, 58(3), 523-533. [Google Scholar] [CrossRef]

Allen, D. K., Colligan, D., Finnie, A., \& Kern, T. (2000). Trust, power and interorganizational information systems: the case of the electronic trading community TransLease. Information Systems Journal, 10(1), 21-40. [Google Scholar] [CrossRef]

Andrus, D. R., \& Turcott, G. (1974). Public land mineral leasing stipulations - the contemporary scene., 437-446. Retrieved from www.scopus.com

Auerbach, A. J. (2002). Chapter 19 taxation and corporate financial policy. In Handbook of public economics (Vol. 3, pp. 1251 1292). Elsevier. [CrossRef]

Aurasmaa, A., Skinner, R., \& Gallop, N. (2020).The ongoing quest for innovation in the asset finance leasing industry. Retrieved from [Link]

Ballardini, R. M., Kaisto, J., \& Similä, J. (2020). Developing novel property concepts in private law to foster the circular economy. Journal of Cleaner Production, 279, 123747. [Google Scholarl [CrossRef]

Baranovskyi, O. I. (2020). Regulation of functional and structural transformational processes in the financial sector. Financial and credit activity: problems of theory and practice, 1(32), 292-306. [Google Scholar] [CrossRef]

Baranovskyi, O. I. (2018). Quality of the transformational processes in the financial sector of the national economy: vectors of the measurement. Financial and credit activity: problems of theory and practice, 3(26), 350-367. [Google Scholar] [CrossRef]

Bardy, R., Rubens, A., \& Eberle, P. (2017). Soft Skills and Job Opportunities of Migrants: Systemic Relationships in the Labour Market. Business Ethics and Leadership. 1(4), 5-21. [Google Scholar]

Baumel, C., \& Wallize, J. (1972). Management considerations in buying and leasing transportation equipment. FEEDSTUFFS, 44(13), 32

Berdeddouch, A., Yahyaouy, A., Bennani, Y., \& Verde, R. (2020). Recommender System for Most Relevant K Pick-Up Points. In International Conference on Artificial Intelligence \& Industrial Applications (pp. 277-289). Springer, Cham. [Google Scholar] [CrossRef]

Birtcher, C. (1959). Leasing medical equipment by hospital or physician. Medical times, 87, 1231.

Brax, S. A., \& Visintin, F. (2017). Meta-model of servitization: The integrative profiling approach. Industrial Marketing Management, 60, 17-32. [Google Scholar] [CrossRef]

CLEO. (2007). The History of Leasing. Retrieved from [Link]

Craig, J. F., Halls, A. S., Barr, J. J. F., \& Bean, C. W. (2004). The Bangladesh floodplain fisheries. Fisheries Research, 66(2-3), 271-286. [Google Scholar] [CrossRef]

Dennis, J. B. (1967). A position paper on computing and communications. In Proceedings of the first ACM symposium on Operating System Principles (pp. 6-1). [Google Scholar] [CrossRef]

Desai, P., \& Purohit, D. (1998). Leasing and selling: Optimal marketing strategies for a durable goods firm. Management Science, 44(11-part-2), S19-S34. [Google Scholar]

Devos, E., \& Li, H. (2020). Do firms lease to hedge? CEO risk-taking and operating lease intensity. European Financial Management. [Google Scholar] [CrossRef]

Fabiano, B., Currò, F., Reverberi, A. P., \& Pastorino, R. (2008). A statistical study on temporary work and occupational accidents: specific risk factors and risk management strategies. Safety science, 46(3), 535-544. [Google Scholar] [CrossRef]

Forgionne, G. A. (1997). HADTS: A decision technology system to support Army housing management. European Journal of Operational Research, 97(2), 363-379. [Google Scholarl [CrossRef]

Grit, L., Irwin, D., Yumerefendi, A., \& Chase, J. (2006). Virtual machine hosting for networked clusters: Building the foundations for" autonomic" orchestration. In First International Workshop on Virtualization Technology in Distributed Computing (VTDC 2006) (pp. 7-7). IEEE. [Google Scholar] [CrossRef]

Grosset, G. (1970). Leasing management and computer. Management controls, 17(6), 126-129.

Irwin, D., Chase, J., Grit, L., Yumerefendi, A., Becker, D., \& Yocum, K. G. (2006). Sharing networked resources with brokered leases. Resource, 6, 6. [Google Scholar]

Kuznyetsova A. Ya., Zherebylo I. V., Klipkova O. I., Kozmuk N. I. (2019). Creation of the value of national enterprises with the help of the innovation centers in the cluster formations. Financial and credit activities: problems of theory and practice, 2(29), 391-402. [Google Scholar] [CrossRef]

Kuznyetsova, A. Y., \& Klishchuk, O. V. (2017). Theoretical conception of price stability targeting arrangement: investigation of basic principles of implementation monetary regime. Financial and credit activity: problems of theory and practice, 2(23), 388-396. [Google Scholar] [CrossRef] 
Loomis, J., Kent, P., Strange, L., Fausch, K., \& Covich, A. (2000). Measuring the total economic value of restoring ecosystem services in an impaired river basin: results from a contingent valuation survey. Ecological economics, 33(1), 103-117. [Google Scholar] [CrossRef]

Nechaev, A. S., Zakharov, S. V., Barykina, Y. N., Vel'm, M. V., \& Kuznetsova, O. N. (2020). Forming methodologies to improving the efficiency of innovative companies based on leasing tools. Journal of Sustainable Finance \& Investment, 1-18. [Google Scholar] [CrossRef]

Palmer, M. A., Lettenmaier, D. P., Poff, N. L., Postel, S. L., Richter, B., \& Warner, R. (2009). Climate change and river ecosystems: protection and adaptation options. Environmental management, 44(6), 1053-1068. [Google Scholar] [CrossRef]

Pantisano, F., Bennis, M., Saad, W., \& Debbah, M. (2012). Spectrum leasing as an incentive towards uplink macrocell and femtocell cooperation. IEEE Journal on Selected Areas in Communications, 30(3), 617-630. [Google Scholar] [CrossRef]

Pierce, L. (2009). Big losses in ecosystem niches: How core firm decisions drive complementary product shakeouts. Strategic management journal, 30(3), 323-347. [Google Scholar] [CrossRef]

Pinkerton, E., \& Edwards, D. N. (2009). The elephant in the room: the hidden costs of leasing individual transferable fishing quotas. Marine Policy, 33(4), 707-713. [Google Scholar] [CrossRef]

Prideaux, D., Ash, J., Broadley, S., Crotty, B., Hart, W., Searle, J., ... \& Worley, P. (2019). Leasing a medical curriculum: What's it worth?. Medical teacher, 41(6), 697-702. [Google Scholar] [CrossRef]

Rampini, A. A., \& Viswanathan, S. (2013). Collateral and capital structure. Journal of Financial Economics, 109(2), 466-492. [Google Scholar] [CrossRef]

Reiner, B., Siegel, E., \& McKay, P. (2000). Adoption of alternative financing strategies to increase the diffusion of picture archiving and communication systems into the radiology marketplace. Journal of digital imaging, 13(1), 108-113. [Google Scholar] [CrossRef]

Santini, J. (1979). Coal leasing and the federal coal management program. Mining Congress Journal, 65(12), 41-43. In mining congress journal (Vol. 65, No. 12, pp. 41-43)

Sotomayor, B., Keahey, K., \& Foster, I. (2008, June). Combining batch execution and leasing using virtual machines. In Proceedings of the 17th international symposium on High performance distributed computing (pp. 87-96). [Google Scholar] [CrossRef]

Thompson, M., \& Homewood, K. (2002). Entrepreneurs, elites, and exclusion in Maasailand: Trends in wildlife conservation and pastoralist development. Human Ecology, 30(1), 107-138. [Google Scholar] [CrossRef]

Vasylieva, T., Bilan, Y., Starchenko, L., \& Woźniak, A. (2020). Green Intellectual capital for sustainable business model: bibliometric analysis. In Proceedings of the 34th International Business Information Management Association (IBIMA) conference.

Verdict Staff. (2013). Meet the future of leasing. Retrieved from [Link]

Viganò, E. (1974). The Accounting Problem of Financial Leasing: A Review. Management International Review, 99-105. [Google Scholar]

Vovchak, O. D., Senyshch, P. M., \& Melnyk, T. V. (2019). «Purging» of the banking system: impacton the key performance indicators of banks. Financial and credit activity: problems of theory and practice, 1(28), 16-25. [Google Scholar] [CrossRef]

Yang, E., Guevara-Ramirez, J. S., \& Bisson, C. (2020). Finding evidence of green leasing in united states government-leased properties. Journal of Green Building, 15(1), 55-72. [Google Scholar] [CrossRef]

Yaraghi, N., \& Ravi, S. (2016). The Current and Future State of the Sharing Economy. Retrieved from [Link]

Zhang, Y., Yao, D., \& Zhang, C. (2020). Bank loan versus financial lease: how do traditional and innovative approaches within the banking sector influence economic growth? A comparative analysis between the US and China. Applied Economics, 1-18. [Google Scholar] [CrossRef]

Зейналов Закір Гаджі, Ph.D., доцент, Азербайджанський економічний університет, Азербайджан Інновації в лізингу та лізинг інновацій: мета-аналіз

У рамках даного дослідження проаналізовано та систематизовано науковий доробок щодо дослідження питань лізингу та інновацій в лізингу. Автор зазначив, що стрімкий розвиток Інтернету, розширення покриття мобільного Інтернету, розповсюдження інтернет-пристроїв, технологічні інновації в фінансовій та страховій сфферах, а також розвиток економіки спільної участі провокують низку наукових дискусій щодо майбутнього інновацій у сфері фінансування та лізингу активів. Головною метою статті є визначення подальших напрямів дослідження питань лізингу інновацій та інновацій в лізингу на основі аналізу публікаційної тенденції науковців з означеної тематики. Емпіричне дослідження проведено з використанням інструментарію програмного забезпечення VOSviewer та наукових баз даних Scopus i Web of Science. Вuхідні данні для дослідження були сфрормовані на основі аналізу 2513 наукових публікацій, опублікованих у наукових журналах, які індексуються базами даних Scopus (1915) ma Web of Science (598). Вибірка дослідження не обмежена у часовому вимірі. Отримані результати свідчать про висхідну тенденцію публікаційної активності з досліджуваної проблематики. Зокрема, встановлено, що темп росту публікацій у базі даних Scopus не $\epsilon$ стабільним. Так, з 2000 до 2010 років спостерігається значне зростання публікаційної активності. При цьому у базі даних Web of Science, темп росту публікаційної активності становить 19,9\%. Так, зростання кількості наукових публікацій з досліджуваної тематики на $412 \%$ у 2019 році, у порівнянні з 2010 роком, свідчить про актуальність дослідження даної проблематики серед широкого кола науковців. При цьому найбільша частка науковців була з США, Китаю, 
Великобританії та Німеччини. За результатами аналізу визначено, що у базі даних Scopus публікації з досліджуваної тематики представлені у різних предметних галузях, а саме: Медицина, Інженерія, Соціальні науки, Екологія, Бізнес, Комп'ютерні науки, Управління та облік. Зокрема, у 2019 році зросла кількість статей, опублікованих науковими журналами з високим імпакт-фрактором, а саме: Land Use Policy, European Journal of Operational Research, Ecology and Society. Таким чином, автор приходить до висновку, що питання лізингу інновацій та інновацій в лізингу є популярним напрямом досліджень в економіці спільної участі. За результатами бібліографрічного аналізу визначено шість кластерів, які свідчать про спрямованість наукових публікацій. Таким чином, найбільший кластер сформований за наступними ключовими словами: сталий розвиток, вплив на навколишнє природне середовище, охорона навколишнього природного середовища, енергетична політика, землекористування, управління земельними ресурсами, управління риболовним господарством, закони та законодавство, оцінка ризиків, тощо. Другий за розміром кластер свідчить про напрям досліджень в галузі інформаційних систем та програмного забезпечення в лізингу. Наступні три кластери мають тісний зв'язок та пов'язані між собою такими ключовими словами як: «лізине - юридичний аспект - управління охороною здоров'я/управління медичною справою - лікарняне обладнання/інформаційні системи лікарень», тощо. Шостий кластер сформований за наступними ключовими словами: фінансовий менеджмент, податки, фінансування капіталовкладень, лізинг - власність, капітальні витрати, облік, правові аспекти, менеджмент, тощо.

Ключові слова: інновації, лізинг, управління лізингом, інновації в лізингу.

\section{Manuscript received: 21.01.2020}

(C) The author(s) 2020. This article is published with open access at Sumy State University 